\title{
Anomalous Origin of Cystic Artery from Gastroduodenal artery - A Case Report
}

\author{
Origen Anómalo de la Arteria Cística desde la Arteria Gastroduodenal - Reporte de un Caso
}

\author{
Vishnumaya, G.; Bhagath, Kumar Potu; Vasavi, Rakesh Gorantla \& Thejodhar, P.
}

\begin{abstract}
VISHNUMAYA, G.; BHAGATH, K. P.; VASAVI, R. G. \& THEJODHAR, P. Anomalous origin of cystic artery from gastroduodenal artery - A case report. Int. J. Morphol., 26(1):75-76, 2008.

SUMMARY: The knowledge of vascular variations, like other anatomical variations, is important during the operative, diagnostic and endovascular procedures in abdomen. Variations in the branching pattern of the common hepatic artery often occur and may be encountered during cholecystectomy. This report describes a variation in the origin of cystic artery from the gastro duodenal artery as found during routine dissection in an approximately 34 years old male cadaver. The embryological development and clinical implications of such a variant have been discussed in the article.
\end{abstract}

KEY WORDS: Cystic artery; Gastroduodenal artery; Vascular variations.

\section{INTRODUCTION}

Anatomical variations of the cystic artery are commonly encountered during cholecystectomy. In most of the cases, the cystic artery arises from the right hepatic artery. The other origins include the left hepatic artery, the proper hepatic artery, the common hepatic artery, the gastroduodenal artery, the superior pancreaticduodenal artery and the superior mesenteric artery (Williams et al., 1989; Price \& Holden, 1993; Harris \& Pellegrini, 1994). In addition to the variability in origin of the cystic artery, its course can also follow diverse

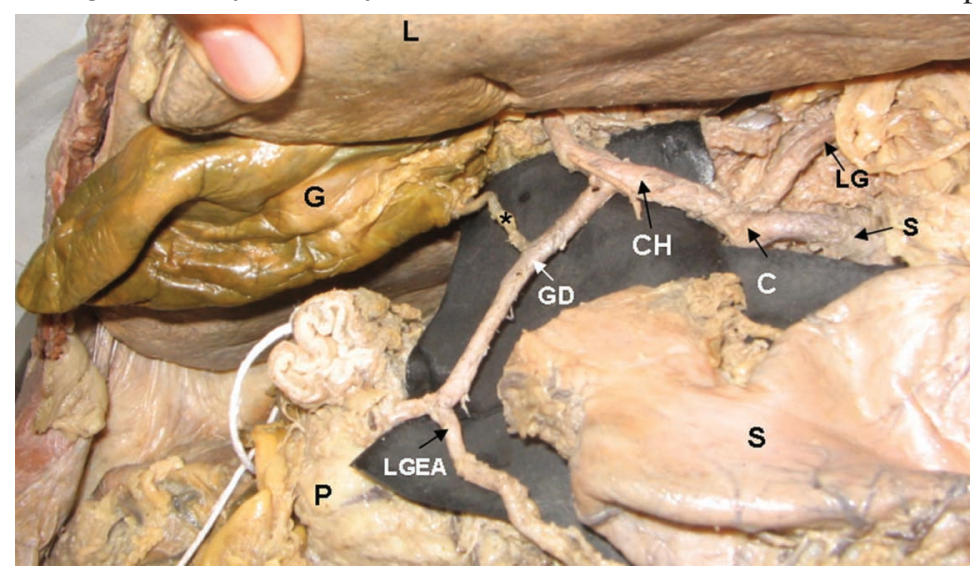

Fig. 1. Diagram showing the origin of cystic artery from the gastroduodenal artery. CH- common hepatic artery; GD- gastro duodenal artery; LGEA- left gastro epiploic artery; C- celiac trunk; LG- left gastric artery; S- splenic artery; L- liver; S- stomach; G- gall bladder; P-pancreas. * showing the cystic artery. paths, often in close proximity to the common bile duct (Price $\&$ Holden). This emphasises the importance of a thorough knowledge of the cystic arterial variations that often occur and may be encountered during both open and laparoscopic cholecystectomy. Uncontrolled bleeding from the cystic artery and its branches is a serious problem that may increase the risk of intraoperative lesions to vital vascular and biliary structures (Hugh et al., 1992; Scott-Conner \& Hall, 1992). This paper presents a rare and, to our knowledge, an

Department of Anatomy, Center for Basic Sciences, Kasturba Medical College, Manipal, Karnataka, India -576104. 


\section{DISCUSSION}

The cystic artery (CA) originates from the following sources: right hepatic $(63 \pm 9 \%)$, hepatic trunk $(26 \pm 9 \%)$, left hepatic $(5 \pm 5 \%)$, gastroduodenal $(2 \pm 6 \%)$, superior pancreaticoduodenal $(0 \pm 3 \%)$, right gastric $(0 \pm 1 \%)$, coeliac trunk $(0 \pm 3 \%)$ and superior mesenteric $(0 \pm 8 \%)$ artery (Anson, 1963). A little difference in origin was noted by Harris \& Pellegrini, where the right hepatic artery was the main contributor (75\%). The other contributors were the left hepatic artery $(6 \pm 2 \%)$, hepatic artery proper $(2 \pm 2 \%)$, common hepatic artery $(0 \pm 6 \%)$, superior pancreatico-duodenal artery $(0 \pm 2 \%)$ and the superior mesenteric artery reported by Anson. In a study by Sarkar \& Roy (2000) the CA originating from the gastroduodenal artery was found once in 96 cases studied $(1 \pm 04 \%)$, which is the lowest within the reported literature. During development, the extrahepatic biliary system arises from an intestinal diverticulum, which carries a rich supply of vessels from the aorta, coeliac trunk and superior mesenteric artery. Later most of these vessels are absorbed, leaving in place the mature vascular system. As the pattern of absorption is highly variable, it is not unusual for the cystic artery and its branches to derive from any other artery in the vicinity (Nowak, 1977).

Laparoscopic cholecystectomy has been accepted as the preferred method of treatment of gall bladder stones in healthy individuals. During laparoscopic cholecystectomy, dissection of a limited field is magnified on the video monitor, which indicates that a detailed anatomical knowledge of the possible variations in the anatomy of the cystic artery and its branches is very important to the surgeon (Hugh et al.; ScottConner \& Hall). The cystic artery arising outside the hepatobiliary triangle usually passes ventral to the common hepatic duct and in some cases it may even be inferior to the cystic duct, thus becoming the first structure encountered in dissection of the inferior border of the hepatobiliary triangle by laparoscopy and has a chance of accidental injury (Hugh $e t$ $a l$.). It is obvious that too proximal a ligation of such a cystic artery would endanger the common hepatic duct. In conclusion, identification of such variation has immense surgical importance and requires special attention in gallbladder surgeries and also helps the radiologist to perform an intraoperative cystic angiogram during hepatobiliary surgery.

VISHNUMAYA, G.; BHAgATH, K. P.; VASAVI, R. G. \& THEJODHAR, P. Origen anómalo de la arteria cística desde la arteria gastroduodenal - Reporte de un caso. Int. J. Morphol., 26(1):75-76, 2008.

RESUMEN: El conocimiento de las variaciones vasculares, al igual que otras variaciones anatómicas, son importantes durante los procedimientos operativos, diagnósticos y endovasculares en el abdomen. Variaciones en el patrón de ramificación de la arteria hepática común se producen con frecuencia y pueden ser encontradas durante la colecistectomía. Este informe describe una variación en el origen de la arteria cística desde la arteria gastroduodenal encontrada durante la disección de rutina, en un cadáver de sexo masculino, de aproximadamente 34 años. El desarrollo embriológico y las implicaciones clínicas de esta variante son debatidas en el artículo.

PALABRAS CLAVE: Arteria cística; Arteria gastroduodenal; Variaciones vasculares.

\section{REFERENCES}

Anson, B. H. The aortic arch and its branches. In Cardiology. New York, McGraw-Hill, 1963. V. 1. p.119.

Harris, H. W. \& Pellegrini, C. A. In Surgical Disease of the Biliary Tract and Pancreas-Multidisciplinary Management Year Book. Braasch \& Tompkins, St Louis, Mosby, 1994. pp.130-2.

Hugh, T. B.; Kelly, M. D. \& Li, B. Laparoscopic anatomy of the cystic artery. Am. J. Surg., 163(6):593-5, 1992.

Nowak, M. Variation of the cystic artery in man. Variation of the cystic artery in man. Folia Morphologica, 36(2):89-98, 1977.

Price, P. \& Holden, C. Anatomic variance in the cholecystic blood supply: a case report. Am. Surg., 59(5):278-80, 1993.

Sarkar, A. K. \& Roy, T. S. Anatomy of the cystic artery arising from the gastroduodenal artery and its choledochal branch-a case report. J. Anat., 197(3):503-6, 2000.
Scott-Conner, C. H. \& Hall, T. J. Variant arterial anatomy in laparoscopic cholecystectomy. Am. J. Surg., 163(6):590-2, 1992.

Williams, P. L.; Warwick, R.; Dyson, M. \& Bannister, L. H. Gray's Anatomy. Edinburgh, Churchill Livingstone, 1989. pp.76872 .

Correspondence to:

Bhagath Kumar Potu

Department of Anatomy

Kasturba Medical College

Manipal-576104

Karnataka

INDIA

Email: potu_kumar2000@yahoo.co.in

Received: 28-06-2007

Accepted: 14-10-2007 